A N N A L ES

UNIVERSITATIS MARIAE CURIE-SKŁODOWSKA

LUBLIN - POLONIA

VOL. LXVI, 1

SECTIO G

2019

Uniwersytet Marii Curie-Skłodowskiej w Lublinie

ANDRZEJ KORYBSKI

andrzej.korybski@poczta.umcs.lublin.pl

ORCID: 0000-0002-7705-0116

\title{
Profesjonalizacja czynności mediacyjnych (wybrane zagadnienia w perspektywie polskiego porządku prawnego)
}

Professionalization of Mediation Activities

(Selected Issues in Perspective of the Polish Legal Order)

\section{WPROWADZENIE}

Zagadnienie profesjonalizacji działalności oraz odpowiedzialności zawodowej mediatora pojawia się w polskim piśmiennictwie prawniczym fragmentarycznie przy okazji analizy szczegółowych kwestii dotyczących mediacji w poszczególnych gałęziach prawa bądź jako fragmenty opracowań podręcznikowych. Taka sytuacja uzasadnia zamiar potraktowania procesu profesjonalizacji czynności mediacyjnych jako zasadniczego przedmiotu rozważań, z uwzględnieniem konsekwencji tego procesu dla kształtowania statusu mediatora $\mathrm{w}$ polskim porządku prawnym. Szczególne znaczenie dla tego procesu ma dokonana ostatnio nowelizacja prawa obowiązującego $\mathrm{w}$ zakresie mediacji w sprawach cywilnych, $\mathrm{w}$ tym zwłaszcza nowelizacja Kodeksu postępowania cywilnego (dalej: k.p.c.) oraz prawa o ustroju sądów powszechnych (dalej: p.u.s.p.) ${ }^{1}$. Nowelizację należy traktować jako wspólną podstawę normatywną dla postępowań mediacyjnych w sprawach cywilnych sensu largo. Zmiany statusu mediatora będą prowadziły, jak można przypuszczać, do zmniejszenia znaczenia instytucji mediatora ad hoc oraz do postępującej profesjonalizacji czynności mediacyjnych w najszerszej grupie spraw, jakimi są sprawy cywilne. Należy przy tym zaznaczyć, że w innych typach

1 Nowelizacja k.p.c. oraz p.u.s.p. została wprowadzona ustawą z dnia 10 września 2015 r. o zmianie niektórych ustaw w związku ze wspieraniem polubownych metod rozwiązywania sporów (Dz.U. 2015, poz. 1595). 
spraw, jakie również mogą być rozwiązywane w drodze mediacji (w tym szczególnie mediacji w sprawach karnych, sprawach dotyczących nieletnich, sprawach rodzinnych czy administracyjnych), przepisy regulujące status mediatora już obecnie w dużym stopniu uwzględniają wymóg profesjonalizmu w dokonywaniu czynności mediacyjnych. W artykule zostaną rozważone wybrane elementy statusu prawnego mediatora oraz jego odpowiedzialności, mające znaczenie dla weryfikacji tezy o postępującej profesjonalizacji czynności mediacyjnych oraz perspektywie przekształcenia zawodu mediatora w zawód regulowany.

\section{WYBRANE ZAGADNIENIA ROLI SPOŁECZNEJ, STATUSU ORAZ ODPOWIEDZIALNOŚCI MEDIATORA}

Pojęcie roli społecznej stanowi punkt wyjścia do konstrukcji statusu prawnego oraz odpowiedzialności mediatora. Rolę społeczną można zdefiniować jako ogół utrwalonych oczekiwań manifestowanych wobec określonych podmiotów społecznych w sytuacjach, w jakich podmioty te powinny zachować się w odpowiedni sposób wobec innych podmiotów (jednostek, grup, instytucji, wspólnot). Zachowania te są z reguły wyznaczone przez normy uznane za wiążące w ramach grupy/wspólnoty oraz jej organizacji. Jeżeli są to normy uznawane za wiążące w ramach najszerszych wspólnot, jakimi są narody oraz państwa lub zrzeszenia państw jako organizacje tych wspólnot, to możemy mówić o publicznej doniosłości takich norm oraz o potrzebie prawnej regulacji danej roli społecznej ${ }^{2}$. W tym znaczeniu można także wyodrębnić społeczną rolę mediatora. Jest ona oparta na oczekiwaniach wyznaczonych przez różne wiążące normy społeczne, w tym normy prawne obowiązujące w organizacji państwowej. Kluczową częścią roli mediatora jest zaś status prawny mediatora rozumiany jako ogół praw i obowiązków wynikających z prawa obowiązującego oraz innych norm wiążących mediatora.

Roli społecznej nie można jednak sprowadzać tylko do oczekiwań sformułowanych jako normy i zawierających wzory zachowań kierowane do zindywidualizowanych podmiotów (w tym jednostek) jako wykonawców roli. Należy wziąć pod uwagę także wymagane od wykonawcy cechy osobowościowe (tzw. wzór osobowy roli) oraz kulturowe uwarunkowania wykonywania danej roli, w tym uwarunkowania edukacyjne (dysponowanie odpowiednią wiedzą, umiejętnościami oraz kompetencjami społecznymi nabytymi w toku różnorodnych procesów socjalizacyjnych) i komunikacyjne (kompetencje językowe i umiejętności perswazyjne w relacjach międzyludzkich). Różnice w kulturowych uwarunkowaniach wykonywania danej roli w porządku prawnym wspólnoty mogą być także

2 Więcej o pojęciach roli społecznej i roli zawodowej w związku z wyodrębnieniem społecznej i zawodowej roli mediatora zob. M. Myślińska, Mediator w polskim porządku prawnym, Warszawa 2018, s. 71-82 i przywołana tam literatura przedmiotu. 
kształtowane przez typ kultury prawnej właściwej dla porządku prawnego danego państwa. Typ kultury jest szczególnie istotny dla wykonywania roli mediatora z uwagi na kulturowo zdeterminowane możliwości włączenia mediatora do sporów. Niezależnie od wielu uniwersalnych cech mediacji i mediatora istnieją znaczące różnice między wykonywaniem roli mediatora w kulturze anglosaskiej oraz w kulturze prawa stanowionego ${ }^{3}$. Istotną cechą wykonywania roli mediatora w porządku prawa stanowionego jest ustawowa regulacja podstawowych zasad postępowania mediacyjnego oraz kluczowej części statusu prawnego mediatora.

Ze względu na rozważany dalej problem zawodu mediatora należy poświęcić kilka uwag szczególnemu typowi roli społecznej, jakim jest rola zawodowa. Istotą roli zawodowej jest społeczne utrwalenie oczekiwań dotyczących dokonywania pewnych czynności w obrocie społecznym jako czynności stanowiących podstawę osiągania przychodów życiowych, a więc czynności skierowanych na zaspokojenie potrzeb i dążeń innych podmiotów społecznych oraz stanowiących dla danej osoby jako wykonawcy roli zawodowej źródło przychodów oraz życiowego utrzymania (tzw. czynności zawodowych). Wyodrębnianie ról zawodowych jest wynikiem specjalizacji w zakresie wytwarzania dóbr oraz oferowania usług potrzebnych innym podmiotom dla zaspokojenia ich potrzeb. Przy wyodrębnianiu roli zawodowej należy zatem określić typ dobra bądź usługi oferowanej przez wykonawcę danej roli, a także kwalifikacje niezbędne dla zapewnienia temu dobru/ usłudze takiej jakości, jaka jest wymagana na rynku zawodowym (a więc rynku umożliwiającym zetknięcie dostawców dobra/usługi z jej odbiorcami). Świadczenie dobra/usługi podlega przy tym odpowiedniej wycenie, ponieważ za wykonanie takiej usługi należy się wykonawcy roli zawodowej odpowiednia zapłata.

Ujęcie roli mediatora jako roli zawodowej wymaga analizy usługi mediacyjnej, a także społecznego zapotrzebowania na usługi mediacyjne. Należy rozważyć szczególne wymagania kierowane do mediatora po to, aby zapewnić odpowiednią jakość i skuteczność usługi mediacyjnej. Należy też odtworzyć normatywny (w tym prawny) wzorzec roli zawodowej mediatora obejmujący zwięzły opis jego praw i obowiązków. Wskazane wyżej zagadnienie zostanie poruszone przede wszystkim w odniesieniu do normatywnego (w tym głównie ustawowego) wzorca roli zawodowej w taki sposób, aby umożliwić charakterystykę odpowiedzialności mediatora w procesie polubownego rozwiązywania sporu cywilnego.

W obecnym stanie prawnym można wyróżnić trzy kategorie mediatorów: mediatorów ad hoc, mediatorów z listy prowadzonej przez ośrodek mediacyjny (zwanych dalej mediatorami) oraz mediatorów wpisanych na listę stałych me-

3 O uwarunkowaniach roli mediatora i społecznych funkcjach mediacji por. m.in. A. Kalisz, Mediacja jako forma dialogu w stosowaniu prawa, Warszawa 2016, s. 110-117; H. Duszka-Jakimko, Alternatywne rozwiąywanie sporów. Pomiędzy instrumentalnym a komunikacyjnym paradygmatem prawa, Opole 2016, s. 115-120. 
diatorów (zwanych dalej stałymi mediatorami). Ogólny wzorzec roli zawodowej mediatora należy traktować jako punkt wyjścia do uchwycenia swoistości różnicujących rolę mediatora w każdej z wyróżnionych kategorii. W przepisach prawnych regulujących mediację w poszczególnych gałęziach prawa nie wymienia się wprost wszystkich zadań i obowiązków, jakie należą do mediatora w związku z podjęciem przez niego usługi mediacyjnej oraz wszczęciem mediacji i jej przebiegiem. Strony sporu, zawierając z mediatorem umowę, powinny w niej dookreślić te zadania i obowiązki. Ogół wzajemnych świadczeń stron oraz mediatora można traktować jako swoistą usługę, co uzasadnia określenie istoty takiej umowy jako umowy o świadczenie usługi mediacyjnej (zwanej też umową mediatorską).

Rozważenia wymaga charakter prawny umowy o świadczenie usługi mediacyjnej. W przeważającej opinii umowa ta prowadzi do powstania zobowiązania starannego działania. Świadczenie mediatora wobec stron polega na dokonywaniu czynności mających na celu ułatwienie rozwiązania sporu przez strony. Sposób rozumienia i zakres czynności ułatwiających rozwiązanie sporu powinny pozostawać w ramach postanowień umowy łączącej strony z mediatorem. Charakter czynności podejmowanych przez mediatora oraz pewne cechy, jakich strony sporu oczekują od osoby mediatora, powodują, że umowa ta powinna być traktowana jako umowa nienazwana prawa cywilnego, do której należy odpowiednio stosować przepisy dotyczące umowy zlecenia ${ }^{4}$. Z punktu widzenia konstrukcji tej umowy może być ona odrębną umową albo umową wkomponowaną w umowę o mediację zawartą między stronami, a także - poprzez tzw. klauzulę mediacyjną - w inną, szerszą umowę materialnoprawną między stronami.

W polskim porządku prawnym mediacja jest prowadzona przez strony z udziałem mediatora na podstawie umowy o świadczenie usługi mediacyjnej pozostającej w związku z umową o mediację zawartą przez same strony, w tym umowy zawartej poprzez wyrażenie - na wniosek drugiej strony - zgody na przeprowadzenie mediacji. Można zatem wyróżnić mediację prowadzoną w związku z umową o mediację, która stanowi alternatywę wobec postępowania sądowego, a także mediację ze skierowania sądu ${ }^{5}$. Podstawą mediacji w tej drugiej sytuacji jest postanowienie sądu o skierowaniu stron do mediacji; mediacja ta jest ściśle związana z postępowaniem sądowym w danej sprawie cywilnej.

W przypadku zgodnych oświadczeń woli stron sporu o przystąpieniu do mediacji i włączeniu osoby mediatora do sporu (mediacja sensu stricto) nie ma wąt-

4 Za: Kodeks posteppowania cywilnego. Komentarz, red. A. Jakubecki, t. 1, Warszawa 2017, s. 339-343. Por. R. Flejszar, K. Gajda-Roszczynialska, Alternatywne metody rozwiazywania sporów ze szczególnym uwzględnieniem mediacji-postępowanie cywilne, [w:] K. Płeszka, J. Czapska, M. Araszkiewicz, M. Pękala, Mediacja. Teoria, normy, praktyka, Warszawa 2017, s. 182-184.

5 Mediację prowadzoną w związku z umową o mediację zawartą przez strony można też określić jako mediację konwencjonalną w odróżnieniu od mediacji prowadzonej na podstawie skierowania sądu. Tak: K. Płeszka, J. Czapska, M. Araszkiewicz, M. Pękala, op. cit., s. 179-180. 
pliwości, że odpowiedzialność mediatora ma charakter kontraktowy, ponieważ wynika ona $\mathrm{z}$ treści stosunku zobowiązaniowego, u którego podstaw leży umowa o mediację. W dwóch pozostałych sytuacjach (mediacji na wniosek jednej ze stron sporu za zgodą drugiej strony oraz mediacji zainicjowanej przez sąd) prawna charakterystyka węzła zobowiązaniowego łączącego strony z mediatorem nie jest już tak oczywista. Gdyby nie można było w tych dwóch sytuacjach ustalić, że mediator ponosi odpowiedzialność kontraktową, to należałoby przyjąć, że jest to odpowiedzialność deliktowa. Jednakże, wziąwszy pod uwagę, że warunkiem wszczęcia postępowania mediacyjnego jest wyrażenie zgody przez obie strony sporu na przystąpienie do mediacji (gdy sprawę kieruje do mediacji sąd) bądź przez drugą stronę (w sytuacji, gdy to pierwsza strona składa wniosek o przystąpienie do mediacji), można przyjąć, że w obu sytuacjach dochodzi do zawarcia umowy między stronami sporu a mediatorem, przy czym jest to umowa dorozumiana, wynikająca z czynności podjętych przez jedną bądź obie strony sporu (a więc per facta concludentia) ${ }^{6}$.

W świetle powyższych ustaleń należy przyjąć, że odpowiedzialność mediatora ma przede wszystkim charakter kontraktowy. Zdecydowana większość obowiązków w relacjach stron sporu z mediatorem wynika z postanowień umownych i obciąża mediatora. To mediator jest dłużnikiem w stosunku do stron jako wierzycieli. Jednakże obowiązki stron sporu (zwłaszcza takie, jak obowiązek odpowiedniego współdziałania z mediatorem jako warunek starannego działania mediatora, a także obowiązek zapłaty wynagrodzenia mediatorowi) powodują, że z punktu widzenia konstrukcji tego stosunku prawnego jest to zobowiązanie wzajemne. Mediatorem musi być w każdej z trzech wskazanych wyżej sytuacji osoba fizyczna znana stronom z imienia i nazwiska lub innych przymiotów i cech pozwalających bez wątpliwości ustalić tożsamość mediatora. Kwestiami wymagającymi skonkretyzowania w treści stosunku zobowiązaniowego są charakter oraz formy świadczenia dłużnika na rzecz wierzyciela/wierzycieli. Świadczenie to (zwane świadczeniem mediacyjnym) polega na podjęciu i dokonywaniu czynności składających się na postępowanie mediacyjne, uzasadnionych celem mediacji oraz jej zasadami. Czynności te są - jak już wcześniej zaznaczono - w ramowy sposób zdefiniowane w przepisach k.p.c. Regulacja ta służy przede wszystkim jako podstawa uściślenia czynności mediacyjnych $\mathrm{w}$ mediacji $\mathrm{w}$ sprawach cywilnych, jednak może być również - z uwzględnieniem swoistości spraw innego typu, dla których ustawodawca również przewidział możliwość sięgnięcia po mediację - odpowiednio wykorzystana w precyzowaniu czynności mediacyjnych w sprawach pracy, konsumenckich, karnych itp.

6 Por. R. Cebula, Mediacja w polskim prawie cywilnym, „Mediator” 2005, nr 34, s. 28; J. Kuźmicka-Sulikowska, Podstawa prawna odpowiedzialności cywilnej mediatora, „ADR. Arbitraż i Mediacja” 2008, nr 3, s. 78-79. 
Można wyróżnić trzy grupy obowiązków, a także idących za tym czynności mediacyjnych. Pierwszą tworzą obowiązki i czynności wynikające z istoty stosunku prawnego między mediatorem a stronami. Są to w pierwszym rzędzie obowiązki mediatora wobec stron sporu, jednakże przy mediacji ze skierowania sądu mogą to być również obowiązki wobec podmiotu (organu) kierującego sprawę do mediacji. Drugą grupę obowiązków i czynności stanowią te, które określają relacje między mediatorem a ośrodkiem mediacyjnym (o ile mediator przynależy do danego ośrodka). Trzecia grupa obejmuje obowiązki i czynności mediatora wobec sądu. Analiza prawnej regulacji obowiązków oraz dopuszczalnych sposobów ich dopełnienia pozwala na ocenę stopnia profesjonalizacji czynności mediatora.

Odpowiedzialność prawna mediatora ze stosunku zobowiązaniowego łączącego go ze stronami aktualizuje się wówczas, gdy mediator jako dłużnik nie wykona bądź nienależycie wykona świadczenie w postaci usługi mediacyjnej względem stron jako wierzycieli. Obowiązek dokonania usługi mediacyjnej jest konkretyzowany poprzez szereg obowiązków dokonania takich czynności, jakie doprowadzą do zrealizowania poszczególnych uprawnień wynikających dla stron jako wierzycieli z umowy o świadczenie usługi mediacyjnej.

\section{CZYNNOŚCI MEDIACYJNE}

Umowa o usługę mediacyjną jako umowa starannego działania wymaga dokładnej specyfikacji czynności ustalonych w umowie jako czynności realizujących świadczenie, utrwalonych społecznie i uznawanych za wiążące. Wzorzec starannego działania jest z reguły przypisywany do odpowiedniej wyodrębnionej roli, jaką może pełnić podmiot prawa cywilnego w obrocie prawnym. Wzorzec ten wyznacza zakres odpowiedzialności mediatora, a jego odtworzenie wymaga specyfikacji wiedzy, umiejętności oraz kompetencji społecznych traktowanych jako niezbędne dla należytego wykonania świadczenia mediacyjnego.

Rozległość spraw posiadających tzw. zdatność mediacyjną pozwala na stwierdzenie, że osoby podejmujące się usługi mediacyjnej powinny dysponować wiedzą o naturze danego sporu, a także szczególnymi umiejętnościami komunikacyjnymi oraz kompetencjami społecznymi. Pomimo intuicyjnie stwierdzanej potrzeby dysponowania przez mediatora zestawem wiedzy, umiejętności i kompetencji niezbędnych dla odpowiedzialnego świadczenia usługi mediacyjnej polski ustawodawca nie zdecydował się na zgłaszane w toku prac legislacyjnych rozwiązanie polegające na jakimś mechanizmie koncesjonowania działalności mediacyjnej. Nie zdecydował się również na rozwiązanie umożliwiające powołanie do życia korporacji zawodowej mediatorów ${ }^{7}$. Została utrzymana regulacja dopuszczająca mediatora ad hoc i charakteryzująca się radykalną redukcją wymogów

7 Za: Kodeks postepowania cywilnego. Komentarz, s. 336. 
wobec takiego mediatora, włącznie z możliwością odstąpienia od zasady zapłaty za usługę mediacyjną oraz od formułowania ostrzejszych wymogów kwalifikacji zawodowych wobec mediatorów, wraz z wymogami etyki zawodowej mediatora. Nawet samo zawarcie ugody przed osobą niespełniającą wymogów pełnienia roli mediatora (poza wymogiem pełnej zdolności do czynności prawnych z uwagi na konieczność dokonywania przez mediatora czynności prawnych zmierzających do podjęcia, prowadzenia i zamknięcia postępowania mediacyjnego) nie wpływa na ważność ugody ${ }^{8}$. Mimo to analiza roli mediatora w powiązaniu ze stanem regulacji prawnej charakteryzującej obowiązki mediatora prowadzi do wniosku, że zamierzeniem ustawodawcy jest zwiększenie wymogów profesjonalizmu mediatora. Profesjonalizacja czynności mediacyjnych dotyczy mediatorów (osób wpisanych na listy mediatorów prowadzone przez ośrodki mediacyjne) oraz stałych mediatorów. Oddzielenie tych dwóch grup mediatorów od mediatorów ad hoc jest uzasadnione przede wszystkim tym, że w przypadku takich mediatorów strony oczekują fachowego świadczenia mediacyjnego, natomiast $\mathrm{w}$ odniesieniu do mediacji sądowej ze skierowania sądu wymóg fachowości musi być traktowany również przez sąd jako przesłanka doboru mediatora $\mathrm{w}$ danej sprawie.

Ogólny opis czynności mediacyjnych oraz związanych z nimi obowiązków mediatora jest zawarty w klasyfikacji zawodów i specjalności ${ }^{9}$. W klasyfikacji rozróżnia się dwie grupy zawodowe w ramach działalności mediacyjnej: ogólny zawód mediatora (kod 263502) oraz wyspecjalizowany zawód mediatora sądowego (kod 263507). Istota zawodu mediatora została określona jako pomoc świadczona stronom sporu - za ich zgodą - w rozwiązaniu bez przemocy istniejącego między nimi konfliktu i osiągnięciu porozumienia, z zachowaniem bezstronności, neutralności oraz poufności postępowania mediacyjnego. Czynności podejmowane przez mediatora powinny prowadzić do: rozpoznania konfliktu; organizowania spotkań mediacyjnych (informacyjnych, pośrednich, „twarzą w twarz”); zapewnienia bezpiecznego i poufnego miejsca dla mediacji, umożliwiającego pełne wykorzystanie technik mediacyjnych; wyjaśnienia stanowisk stron, ich interesów oraz granic

8 Właśnie takie stanowisko przeważa w doktrynie (co do argumentacji na rzecz tego stanowiska zob. ibidem). Należy jednak odnotować, że w odniesieniu do mediatorów w niektórych typach spraw (np. w sprawach karnych, nieletnich, o rozwód i separację) oraz do stałych mediatorów zakres wymogów jest ustawowo określony znacznie szerzej, a ich niespełnienie przez mediatora rodzi skutek w postaci odpowiedzialności prawnej.

9 Rozporządzenie Ministra Pracy i Polityki Społecznej z dnia 7 sierpnia 2014 r. w sprawie klasyfikacji zawodów i specjalności na potrzeby rynku pracy oraz zakresu jej zastosowania (t.j. Dz.U. 2018, poz. 227). Klasyfikacja ta stanowi spis zawodów i specjalności zidentyfikowanych - na podstawie Międzynarodowego Standardu Klasyfikacji Zawodów ISCO-08 - na polskim rynku pracy. W tej klasyfikacji działalność mediacyjna jest zaliczona do działalności profesjonalnej w grupie specjalistów do spraw społecznych (2635), od których wymagany jest wysoki poziom wiedzy zawodowej, umiejętności i doświadczenia, uzyskiwanych poprzez odpowiednie studia wyższe, praktykę zawodową oraz samodoskonalenie zawodowe. 
kompromisu; umiejętnego wykorzystania pomocy doradców prawnych oraz innych ekspertów; przełamywania impasu w postępowaniu mediacyjnym; pomocy w sformułowaniu ugody; sprawdzania realności wykonania ugody. Profesjonalne dokonywanie czynności w ramach zawodu mediatora wymaga wyspecjalizowanej wiedzy o relacjach społecznych oraz ich społeczno-instytucjonalnych uwarunkowaniach, w tym wiedzy o konfliktach i sposobach ich opanowywania, a także umiejętności komunikacyjnych i odpowiednich kompetencji społecznych umożliwiających efektywne pośredniczenie mediatora pomiędzy stronami sporu (w tym diagnozę podłoża konfliktu, zorganizowanie i przeprowadzenie postępowania mediacyjnego oraz wypracowanie realnej ugody). Niezbędna jest również wyspecjalizowana wiedza prawna pozwalająca na wstępną kwalifikację prawną sporu oraz efektywne korzystanie z pomocy doradców prawnych.

Do obowiązków mediatora należy skomunikowanie stron oraz określenie najważniejszych spraw, jakie należy ustalić co do przedmiotu mediacji i jej ograniczeń. Dla efektywności mediacji istotne są też odpowiednie przygotowanie i zaplanowanie przebiegu mediacji oraz wybór najkorzystniejszej strategii mediacyjnej. Jednym z obowiązków mediatora jest zebranie najważniejszych informacji o sporze i jego uwarunkowaniach. Zdefiniowanie przedmiotu sporu między stronami oraz analiza powstałych w świadomości stron barier (w tym barier psychicznych) umożliwiają realizację kolejnych obowiązków mediatora, których zakres zależy od ustalonej przez mediatora - w porozumieniu ze stronami - strategii mediacyjnej. Odpowiednią wiedzę i umiejętności mediacyjne mediatora weryfikują odpowiednie procedury wpisu na ośrodkową listę mediatorów oraz przyjęty w ośrodku system kursów i szkoleń doskonalących. Zwróćmy jeszcze uwagę na to, że dokonanie wskazanych w umowie czynności mediacyjnych może być uzależnione od dysponowania przez mediatora odpowiednim sprzętem, infrastrukturą lub odpowiednio zorganizowanym zespołem ludzi. Realizację tych warunków gwarantuje mediatorowi zrzeszonemu jego ośrodek mediacyjny.

Charakterystyka zawodu mediatora sądowego obejmuje zwiększony zakres czynności wymagających profesjonalnego przygotowania, a także uszczegółowienie oczekiwań formułowanych wobec mediatora. Celem jego działalności jest pomoc świadczona stronom sporu dla osiągnięcia porozumienia w sprawach cywilnych, rodzinnych, pracowniczych, gospodarczych oraz karnych. Mediator sądowy powinien wysłuchać strony oraz poddać analizie ich racje w ramach profesjonalnie zorganizowanego postępowania mediacyjnego, zapewniającego stronom poczucie bezpieczeństwa i równowagi wzajemnych relacji. Powinien również doprowadzić do ugody spisanej w odpowiednim dokumencie, spełniającym profesjonalne wymogi aktu prawnego oraz zapewniającym stronom satysfakcję materialną, psychologiczną i proceduralną. Odpowiednie przygotowanie i przeprowadzenie sesji mediacyjnych wymaga podjęcia szeregu czynności. Zgodnie $\mathrm{z}$ treścią art. $183^{11}$ k.p.c. mediator niezwłocznie ustala termin i miejsce posiedze- 
nia mediacyjnego. Wyznaczenie posiedzenia mediacyjnego nie jest wymagane, jeżeli strony zgodzą się na przeprowadzenie mediacji bez posiedzenia. Z przebiegu mediacji mediator powinien sporządzić protokół, w którym oznacza się miejsce i czas przeprowadzenia mediacji, imiona i nazwiska (nazwy) oraz adresy stron, imię i nazwisko oraz adres mediatora, a ponadto opisuje się rezultat mediacji. Mediator ma obowiązek podpisać protokół oraz - niezależnie od wyniku mediacji - doręczyć stronom jego odpis. W sytuacji, gdy mediacja zakończyła się ugodą, należy treść ugody zamieścić w protokole albo dołączyć go jako załącznik do protokołu. Strony powinny podpisać ugodę, a jeśli tego nie mogły uczynić, mediator powinien potwierdzić zawarcie ugody w protokole. Podpisanie ugody albo wzmianka mediatora o zaakceptowaniu ugody przez strony sporu rodzi z kolei obowiązek mediatora wystąpienia do sądu z wnioskiem o zatwierdzenie ugody, połączonego ze złożeniem protokołu z posiedzenia mediacyjnego.

Wykaz czynności zawodowych mediatora sądowego obejmuje:

- analizę istoty konfliktu w sprawach rodzinnych, cywilnych, pracowniczych, gospodarczych oraz karnych,

- nawiązanie kontaktu z każdą ze stron sporu oraz ustalenie terminu spotkania wstępnego,

- analizę uwarunkowań konfliktu oraz przygotowanie planu postępowania mediacyjnego, sprecyzowanie stanowisk stron, określenie rzeczywistych celów i potrzeb porozumienia, przedstawienie zasad mediacji oraz umowy o świadczenie mediacyjne,

- ustalenie właściwej strategii prowadzenia mediacji, budowę zaufania i wzajemnej otwartości stron poprzez spotkania ze stronami sporu (indywidualne i wspólne),

- udzielanie pomocy w komunikowaniu się osobom zaangażowanym w spór w celu umożliwienia im wzajemnego zrozumienia, osiągnięcia porozumienia i zawarcia ugody,

- wspólne negocjowanie rozwiązań i weryfikację ich wykonalności pod kątem zgodności z prawem, słuszności, praktyczności, wykonalności i trwałości,

- uświadamianie stronom potencjalnych skutków braku ugody,

- dokumentowanie mediacji: sporządzenie i podpisanie ugody, doprowadzenie do podpisania ugody przez strony w obecności mediatora,

- złożenie protokołu w sądzie po zakończeniu mediacji wraz z dołączoną do niego ugodą, doręczenie odpisów protokołu stronom sporu,

- dbałość o poprawność formalno-prawną osiągniętej ugody, a także o realność i wykonalność jej rozwiązań,

- przestrzeganie zasad etyki mediatora, takich jak: dobrowolność poddania się mediacji, zakaz wywierania nacisku przez mediatora na strony, poufność mediacji, bezstronność i zakaz pobierania przez mediatora dodatkowych korzyści, bezpieczeństwo stron, neutralność, szybkość i efektywność postępowania, 
- czuwanie przez mediatora nad zgodnością z prawem porozumienia osiągniętego przez strony.

Realizacja wskazanego wyżej szczegółowego katalogu czynności mediatora oraz mediatora sądowego wymaga profesjonalnego przygotowania $\mathrm{w}$ zakresie niezbędnej wiedzy, umiejętności oraz kompetencji i wymogów etycznych. W obecnym stanie prawnym nabycie tej wiedzy, opanowanie odpowiednich umiejętności oraz pozytywną weryfikację kompetencji społecznych i wymogów etycznych powierzono wyspecjalizowanym organizacjom skupiającym mediatorów, prowadzącym proces profesjonalnego przygotowania mediacyjnego oraz weryfikującym osiągnięcie pożądanych efektów kształcenia i nabycia odpowiedniego doświadczenia mediacyjnego. Profesjonalizm mediatora sądowego wzmacnia wymóg prowadzenia własnej działalności gospodarczej przez mediatora w odpowiedniej kancelarii bądź biurze. Należy jednak zauważyć, że w odniesieniu do umiejętności mediacyjnych podmioty zrzeszające mediatorów lub prowadzące szkolenia dla mediatorów często formułują wymóg nabycia odpowiednich umiejętności i kompetencji społecznych jako podstawowy wymóg niezbędny do prowadzenia działalności mediacyjnej; posiadanie wiedzy na temat mediacji traktują zaś jako wymóg wtórny, wypełniany już w trakcie praktyki mediacyjnej.

Dążenie do zwiększenia profesjonalnego przygotowania mediatora jest widoczne zwłaszcza w odniesieniu do stałego mediatora. Jest nim mediator wpisany na listę stałych mediatorów decyzją prezesa odpowiedniego sądu okręgowego. Uzasadnieniem wprowadzenia instytucji stałego mediatora było podniesienie prestiżu zawodu mediatora wśród zawodów obsługujących wymiar sprawiedliwości, a także wymogów etycznych i deontologicznych stawianych mediatorowi. Zgodnie z art. $436 \S 4$ k.p.c., jeżeli strony nie uzgodniły osoby mediatora, sąd kieruje je do stałego mediatora posiadającego wiedzę teoretyczną, w szczególności posiadającego wykształcenie wyższe z zakresu psychologii, pedagogiki, socjologii lub prawa oraz umiejętności praktyczne w zakresie prowadzenia mediacji w sprawach rodzinnych ${ }^{10}$. Przepisy art. 157a-157f p.u.s.p. określają kwalifikacje stałego mediatora i tryb nadzoru nad wykonywaniem przez niego czynności mediacyjnych. Status prawny stałego mediatora cechuje się pewnymi nowymi uprawnieniami i obowiązkami w porównaniu ze statusem prawnym pozostałych mediatorów. Prezes sądu okręgowego uzyskał również możliwość weryfikacji działalności zawodowej stałego mediatora oraz skreślenia go z listy w sytuacji, w której zostały do niego zgłoszone uzasadnione zastrzeżenia ocenione jako nienależyte wykonywanie obowiązków stałego mediatora. Stałym mediatorem może być osoba fizyczna, która zgodnie z art. 157a p.u.s.p. spełnia podstawowe warunki stawiane mediatorowi, a ponadto ukończyła 26 lat, posiada wiedzę i umiejętności w zakresie prowadzenia mediacji, zna język polski, nie była prawomocnie ska-

10 Por. A. Zienkiewicz, Mediator w sprawach cywilnych, „Rejent” 2005, nr 5, s. 142. 
zana za umyślne przestępstwo lub umyślne przestępstwo skarbowe oraz została wpisana na listę stałych mediatorów prowadzoną przez prezesa odpowiedniego sądu okręgowego. Dodatkowe wymogi co do niezbędnej wiedzy i umiejętności stałego mediatora zostały określone dość ogólnie. Wymogi te spełniają przede wszystkim mediatorzy profesjonalnie przygotowani do wykonywania czynności mediacyjnych, wpisani na listy mediatorów prowadzone przez odpowiednie ośrodki mediacyjne. $\mathrm{W}$ ich przypadku bowiem w praktyce nie pojawia się problem nieudokumentowania dotychczasowej praktyki w zakresie mediacji oraz zaliczonych kursów i szkoleń doskonalących wiedzę i umiejętności mediacyjne.

W odniesieniu do wzorca należytej staranności stałego mediatora należy stwierdzić, że obowiązujące przepisy pozwalają na rozbudowanie oczekiwań profesjonalizmu czynności mediacyjnych. Prezes sądu okręgowego został upoważniony do stwierdzania zachowania bądź niezachowania należytej staranności, a tym samym do badania stopnia przygotowania zawodowego mediatora (jego wiedzy, umiejętności i kompetencji społecznych) z punktu widzenia odpowiedniego wzorca mediatora funkcjonującego w środowisku zawodowych mediatorów, a także oczekiwań wobec mediatorów formułowanych w środowisku sędziowskim. Praktyka korzystania z tego upoważnienia dopiero się tworzy, w związku z czym treści tego wzorca są na etapie kształtowania. Rozwiązania zmierzające do zwiększenia profesjonalizmu stałych mediatorów należy jednak uznać za nie w pełni konsekwentne. Mimo obarczenia sądu obowiązkiem nadzoru nad działaniami stałych mediatorów przepisy nie przewidują, aby Skarb Państwa ponosił odpowiedzialność za działania stałego mediatora. Stały mediator, jak również inny mediator wyznaczony przez sąd, nie ma obowiązku zawarcia umowy o odpowiedzialności cywilnej za szkody wyrządzone w związku z mediacją. Należy dodać, że traktowanie mediatora stałego jako wyodrębnionego zawodu obsługującego wymiar sprawiedliwości można dostrzec też w zróżnicowaniu możliwości odstąpienia mediatora od umowy. O ile mediator niewystępujący jako stały mediator może odmówić prowadzenia mediacji w ciągu tygodnia od doręczenia mu wniosku o mediację z każdej przyczyny, której nie musi ujawniać, o tyle stały mediator musi podać ważny powód odmowy, a ważność ta podlega kontroli sądu.

\section{PROBLEM ZAWODU MEDIATORA}

Dokonana w poprzednich punktach charakterystyka obowiązków oraz odpowiadających im czynności mediacyjnych dowodzi tezy o postępującej profesjonalizacji roli mediatora w polskim porządku prawnym. Społeczne i prawne utrwalenie roli zawodowej mediatora uzasadnia wprowadzenie przez ustawodawcę zawodu mediatora do klasyfikacji zawodów, w tym wyodrębnienie zawodu mediatora sądowego jako jednego z zawodów związanych z funkcjonowaniem wymiaru sprawiedliwości. Jest dyskusyjne, czy postępująca profesjonalizacja czyn- 
ności mediacyjnych powinna skutkować rezygnacją z możliwości doboru przez strony mediatora ad hoc, niezrzeszonego w żadnym ośrodku mediacyjnym. Wydaje się, że taki mediator powinien być dalej dostępny dla podmiotów prawa cywilnego w odniesieniu do sporów, których strony nie kierowałyby do sądu (w tym zwłaszcza drobnych sporów pracowniczych, sąsiedzkich itp.). Jednak w sytuacji ugody kierowanej do zatwierdzenia przez sąd, a także mediacji podejmowanej już po zawiśnięciu sprawy w sądzie wymóg odpowiedniego przygotowania zawodowego mediatorów wydaje się oczywisty i sprzyjający bezpieczeństwu prawnemu w obrocie cywilnoprawnym.

Kontrowersyjna pozostaje kwestia ustawowej regulacji zawodu mediatora jako zawodu regulowanego. Postulat zawodu mediatora jako zawodu regulowanego ustawowo jest wysuwany od co najmniej kilku lat przez środowisko mediatorów. Można uznać, że postulat ten został częściowo zrealizowany poprzez wprowadzenie do p.u.s.p. przepisów o stałych mediatorach i umieszczenie ich w grupie przepisów regulujących inne niż sędziowie grupy zawodowe działające w sądach powszechnych (jak referendarze, kuratorzy, pracownicy administracyjni). Ustawowa regulacja statusu prawnego mediatora dotyczy jednak tylko stałych mediatorów. Jest to przy tym regulacja cząstkowa w porównaniu z ustawową regulacją innych zawodów regulowanych, choćby takich jak adwokaci czy radcowie prawni. Nie obejmuje ona całego środowiska mediatorów ani nie reguluje wielu ważnych kwestii, jak np. kwestie samorządu zawodowego mediatorów oraz kompetencje organów tego samorządu, kompleksowa regulacja wymogów wejścia do grupy zawodowej mediatorów oraz praw i obowiązków mediatora (w tym obowiązków etyki zawodowej). Należy więc stwierdzić, że dokonane ustawowe wzmocnienie mediatorów jest wzmocnieniem wymogu profesjonalizacji obowiązków oraz czynności mediacyjnych, jednakże nie można jeszcze mówić o mediatorze jako zawodzie regulowanym.

W państwach europejskich objętych kulturą prawa stanowionego ukształtowały się dwa modele ustawowej regulacji zawodu mediatora ${ }^{11}$. W pierwszym modelu zawód mediatora i postępowanie mediacyjne są regulowane fragmentarycznie w wielu aktach ustawowych, w tym w kodeksach postępowania sądowego. W drugim modelu regulacja mediacji jest zawarta $\mathrm{w}$ jednym akcie o charakterze legi generali, co nie wyklucza regulacji pewnych kwestii istotnych dla zawodu mediatora oraz postępowania mediacyjnego w innych ustawach. Jednak i w tym modelu nie ma odrębnej regulacji ustawowej dotyczącej samego

11 Pierwszy model został przyjęty w większości państw członkowskich UE (m.in. w Belgii, Danii, Francji, Holandii, Portugalii), drugi zaś w Austrii, Bułgarii, Rumunii, Estonii i Finlandii. Por. K.J. Hopt, F. Steffek, Mediation: Principles and Regulation in Comparative Perspective, Oxford 2013, passim. Por. także: W. Broński, P. Sławicki, Mediator: czy potrzebna jest specjalna ustawa?, www.rp.pl/artykul/1093170-Bronski-Slawicki-o-mediacji [dostęp: 27.06.2017]. 
zawodu mediatora. Analiza prawnoporównawcza pozwala zatem na sformułowanie tezy o dotychczasowej wystarczalności rozproszonej regulacji ustawowej zarówno zawodu mediatora, jak i postępowania mediacyjnego (a raczej postępowań mediacyjnych, ponieważ różnicują się one zgodnie z charakterem i zakresem regulacji prawnej na mediacje w sprawach cywilnych, rodzinnych, pracowniczych, karnych, publicznych/administracyjnych itp.). Zmiana społecznych i publicznych stereotypów dotyczących podejścia do sytuacji konfliktowych oraz utrwalanie społecznej postawy potrzeby negocjowania i koncyliacyjności może jednak prowadzić do potrzeby ustawowej regulacji mediacji jako takiej oraz zawodowej roli mediatora. Sytuacja ta będzie sprzyjać przyjmowaniu przez państwa członkowskie UE regulacji zawodu mediatora jako kolejnego zawodu regulowanego.

Istotnym krokiem w tym kierunku wydaje się wprowadzanie oraz rozwijanie krajowych systemów akredytacji mediatorów stwarzających takie same bądź podobne wymagania dla wszystkich mediatorów dążących do specjalizacji w określonym typie sporów sądowych. Można byłoby rozważyć także wprowadzenie jednolitych standardów etyki i deontologii zawodowej mediatorów, jak również spójnego systemu szkoleń oraz innych form podnoszenia kwalifikacji mediacyjnych. Nie ulega wątpliwości, że wprowadzenie takich rozwiązań wiązałoby się z kolejnymi zmianami statusu prawnego mediatora oraz zaostrzaniem wymogów w zakresie wzorca starannego działania mediatorów sądowych. Tendencje te są już teraz wyraźnie obecne w porządkach prawnych wielu państw europejskich. Są one dodatkowo wzmacniane rekomendacjami Komitetu Ministrów Rady Europy oraz dyrektywami Unii Europejskiej. Utrwalaniu tych tendencji służą też wzorcowe regulacje dotyczące standardów etyki zawodowej mediatorów, a także wymogów logistyczno-organizacyjnych kierowanych do mediatorów w związku z organizacją i przeprowadzeniem postępowania mediacyjnego. Ośrodki zrzeszające mediatorów często wprowadzają odpowiednie wymogi w zakresie wiedzy i umiejętności, a niekiedy wręcz w postaci wymogu ukończenia odpowiedniego kierunku studiów wyższych lub dodatkowo kursów szkoleniowych w odniesieniu do specjalizacji mediacyjnej danego mediatora (np. mediacji w sprawach rodzinnych i opiekuńczych). Pośrednio posiadanie specjalistycznej wiedzy i umiejętności przez mediatora może być wymogiem w stosunku do mediacji prowadzonych zwłaszcza ze skierowania sądu. Należy w tym miejscu dodać, że pewien minimalny zakres profesjonalnej wiedzy, umiejętności i kompetencji wymaganych od mediatora został w Polsce określony przez Społeczną Radę do spraw Alternatywnych Metod Rozwiązywania Konfliktów i Sporów ${ }^{12}$.

12 Uchwała Społecznej Rady do spraw Alternatywnych Metod Rozwiązywania Konfliktów i Sporów - Standardy Szkolenia Mediatorów, za: A. Kalisz, A. Zienkiewicz, Mediacja sądowa i pozasadowa. Zarys wyktadu, Warszawa 2014, s. 277-282. 
$\mathrm{Na}$ koniec należy podjąć kwestię ubezpieczenia mediatora od ewentualnych szkód powstałych w związku z wykonaniem usługi mediacyjnej. Zawieranie umów ubezpieczeniowych z odpowiednim ubezpieczycielem przez mediatora ad hoc jest mało prawdopodobne w szerszej skali społecznej. Trudnością jest tu oszacowanie możliwego ryzyka oraz wypracowanie odpowiednich schematów umowy ubezpieczeniowej. Nie wydaje się jednak, aby firmy ubezpieczeniowe były zainteresowane w szerszym wymiarze oferowaniem takich usług ubezpieczeniowych. Inaczej przedstawia się kwestia ubezpieczenia mediatorów skupionych w ośrodkach mediacyjnych. Ośrodki te mogą ubezpieczenie od odpowiedzialności cywilnej stawiać jako wymóg wpisu na listę mediatorów zrzeszonych w danym ośrodku. Osobną kwestią jest obowiązkowe ubezpieczenie od odpowiedzialności cywilnej mediatorów. Postuluje się wprowadzenie ustawowego obowiązku mediatorów do ubezpieczania swojej działalności od odpowiedzialności cywilnej na wzór konstrukcji ubezpieczeniowej narzuconej ustawowo przedstawicielom wielu wolnych zawodów jako zawodów regulowanych (np. adwokatów czy radców prawnych). Wprowadzenie obowiązkowego ubezpieczenia OC jako obowiązku mediatorów wymagałoby pełnej profesjonalizacji zawodu mediatora, a zatem także rezygnacji z instytucji mediatora ad hoc. Wiązałoby się to jednak z wprowadzeniem obowiązkowej przynależności mediatorów do ogólnopolskiej organizacji mediatorów o charakterze samorządowym oraz z przekształceniem zawodu mediatora w zawód regulowany.

\section{BIBLIOGRAFIA}

Broński W., Sławicki P., Mediator: czy potrzebna jest specjalna ustawa?, www.rp.pl/artyku1/1093170-Bronski-Slawicki-o-mediacji [dostęp: 27.06.2017].

Cebula R., Mediacja w polskim prawie cywilnym, „Mediator” 2005, nr 34.

Duszka-Jakimko H., Alternatywne rozwiązywanie sporów. Pomiędzy instrumentalnym a komunikacyjnym paradygmatem prawa, Opole 2016.

Flejszar R., Gajda-Roszczynialska K., Alternatywne metody rozwiązywania sporów ze szczególnym uwzględnieniem mediacji - postępowanie cywilne, [w:] K. Płeszka, J. Czapska, M. Araszkiewicz, M. Pękala, Mediacja. Teoria, normy, praktyka, Warszawa 2017.

Hopt K.J., Steffek F., Mediation: Principles and Regulation in Comparative Perspective, Oxford 2013.

Kalisz A., Mediacja jako forma dialogu w stosowaniu prawa, Warszawa 2016.

Kalisz A., Zienkiewicz A., Mediacja sądowa i pozasądowa. Zarys wykładu, Warszawa 2014.

Kodeks postępowania cywilnego. Komentarz, red. A. Jakubecki, t. 1, Warszawa 2017.

Kuźmicka-Sulikowska J., Podstawa prawna odpowiedzialności cywilnej mediatora, „ADR. Arbitraż i Mediacja” 2008, nr 3.

Myślińska M., Mediator w polskim porządku prawnym, Warszawa 2018.

Płeszka K., Czapska J., Araszkiewicz M., Pękala M., Mediacja. Teoria, normy, praktyka, Warszawa 2017.

Rozporządzenie Ministra Pracy i Polityki Społecznej z dnia 7 sierpnia 2014 r. w sprawie klasyfikacji zawodów i specjalności na potrzeby rynku pracy oraz zakresu jej zastosowania (t.j. Dz.U. 2018, poz. 227). 
Ustawa z dnia 17 listopada 1964 r. - Kodeks postępowania cywilnego (t.j. Dz.U. 2016, poz. 1822). Ustawa z dnia 27 lipca 2001 r. - Prawo o ustroju sądów powszechnych (t.j. Dz.U. 2018, poz. 23 z późn. $z m$.).

Ustawa z dnia 10 września 2015 r. o zmianie niektórych ustaw w związku ze wspieraniem polubownych metod rozwiązywania sporów (Dz.U. 2015, poz. 1595).

Zienkiewicz A., Mediator w sprawach cywilnych, „Rejent” 2005, nr 5.

\section{SUMMARY}

The 2015 amendments to the acts regulating mediation in the Polish legal order have intensified a trend of professionalization of mediator's activities. Although the possibility for the parties to choose ad hoc mediator (without any professional requirements) was maintained, the amendments have introduced the so-called permanent mediator, i.e. a professionally equipped person appointed by judge to mediate in a court dispute. Entry on the list of permanent mediators kept by district courts was made conditional on showing that a mediator has the appropriate, professional knowledge and skills. Currently, such skills and knowledge can be acquired in mediation centers. These centers run professional courses and training in many aspects of mediation. They also enable professional specialization in the field of civil, commercial, family, and other types of disputes. Currently, professionally prepared mediators and judges involved in mediation proceedings are proposing the transformation of mediator's profession into so-called regulated professions defined by a special parliamentary act on mediation and mediators. The presented article adopts an European perspective on the regulation of mediation and looks at the need for the possible transformation concerning the profession of mediator as regulated profession, as well as its limitations and the associated challenges.

Keywords: mediator; legal status; professional knowledge and abilities; civil liability; professional liability

\section{STRESZCZENIE}

Dokonana w 2015 r. zmiana regulacji ustawowych dotyczących postępowania mediacyjnego i statusu prawnego mediatora wzmocniła profesjonalizację czynności podejmowanych przez mediatora w postępowaniu mediacyjnym. Została, co prawda, utrzymana możliwość doboru mediatora ad hoc przez strony sporu, ale w odniesieniu do mediacji sądowej wprowadzono instytucję stałego mediatora wyznaczonego przez sąd. Zarówno wpis na listę stałych mediatorów, jak i wyznaczanie ich do prowadzenia mediacji $\mathrm{w}$ ramach postępowania sądowego zostały uzależnione od zawodowej wiedzy, umiejętności i kompetencji mediatora. Obecnie wiedzę, umiejętności oraz kompetencje można uzyskać przede wszystkim w ramach ośrodków mediacyjnych. Praktyka funkcjonowania tych ośrodków pozwala na stwierdzenie, że kandydaci do zawodu mediatora muszą przejść profesjonalne szkolenie oraz nabyć umiejętności w praktyce mediacyjnej. Spełnienie tych wymogów pozwala mediatorom wnioskować o wpis na listę stałych mediatorów. Mediatorzy skupieni w ośrodkach mediacyjnych oraz sędziowie wykorzystujący mediację w praktyce sądowej postulują uchwalenie ustawy o mediacji i zawodzie mediatora na wzór regulacji ustawowych obowiązujących już w części państw europejskich. W artykule zostały rozważone argumenty dotyczące możliwości przekształcenia dotychczasowych fragmentarycznych regulacji mediacji i zawodu mediacji w zawód regulowany.

Słowa kluczowe: mediator; status prawny; profesjonalna wiedza i umiejętności; odpowiedzialność cywilna; odpowiedzialność zawodowa 